\title{
The influence of networks and decision-making orientation on value creation in technology-based entrepreneurial businesses
}

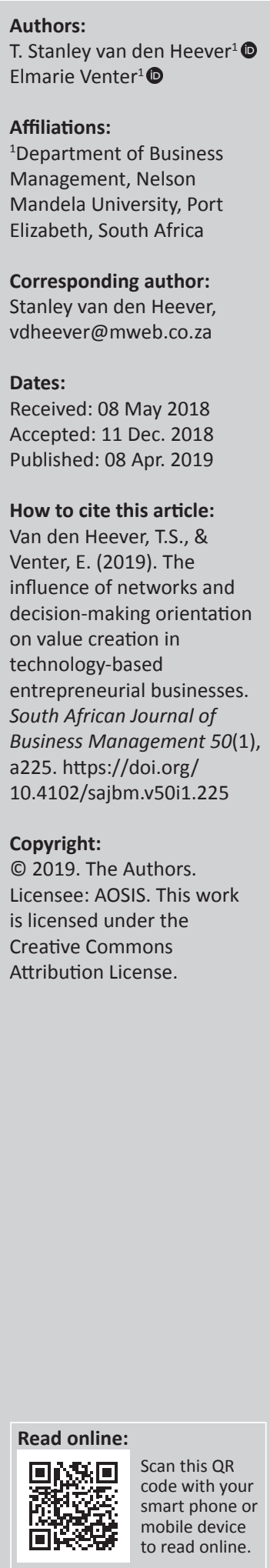

Background: Technology-based entrepreneurial businesses (TBEBs) have been identified as major contributors to economic growth and job creation in most global economies.

Aim: The objective of this study was to empirically test the relationships between structured and unstructured networks and perceived value creation in 313 TBEBs, taking into account their decision-making orientation.

Setting: TBEBs in the South African were identified and information was gathered through structured questionnaires.

Methods: After an exploratory factor analyses (EFA), Cronbach's alpha coefficients were calculated to confirm the validity and reliability of the measuring instrument. Structural equation modelling (SEM) was the main statistical procedure used to test the significance of the relationships hypothesised between the various independent, mediating and dependent variables.

Results: The main finding of the study was that TBEBs can create financial and non-financial value by adopting a decision-making orientation in the business to co-create the future with other stakeholders.

Conclusion: In conclusion this study found that establishing both structured and unstructured networks enhances a co-creation decision-making orientation and contributes to value creation in TBEBs.

Keywords: technology-based entrepreneurial business; decision-making orientation; value creation; structured networks; unstructured networks.

\section{Introduction}

Entrepreneurial businesses play a key role in addressing unemployment and promoting economic growth in countries all over the world (Acemoglu, 2012; Memili, Fang, Chrisman, \& De Massis, 2015). Studies conducted in developed and developing economies, have established the relationship between entrepreneurship and economic growth and value creation (Acemoglu, 2012; Audretsch, Belistji, \& Desai, 2015; Chen, Chang, \& Lee, 2015).

The major contributors to the high economic growth and value creation since the beginning of the 21st century in China were identified as being technology-based entrepreneurial businesses (TBEBs) (Sjöholm \& Lundin, 2010). These businesses are based on existing and emerging technologies, developed through research and development (R\&D) and exploited by entrepreneurial actions, and form part of high-expectation entrepreneurship activity (HEA) (Autio, 2005:10), contributing most to value creation. These businesses are defined as those newly formed businesses which are expected to create a significant number of new job opportunities (Autio, 2005:10).The value created by these TBEBs is multi-dimensional, as not only financial value but also intangible non-financial value is created for the owner and/or entrepreneurial team in terms of autonomy, job satisfaction and innovation (Mian, Lamine, \& Fayolle, 2016).

\section{Problem statement}

While the financial contribution to value creation is easy to quantify, it is far more difficult to determine the contribution of the intangible non-financial value to value creation in TBEB. In other words, the problem statement of this research is that little is known about the intangible non-financial value creation in TBEB. More specifically, little is known about the relationships 
between value creation, networking and decision-making orientation by innovative and technically minded entrepreneurs operating in TBEBs.

Technology-based entrepreneurial businesses create value when they successfully commercialise an innovation (Bosma, Content, Sanders, \& Stam, 2018; Mian et al., 2016). The ability to create and apply knowledge is primarily responsible for creating value in a new business, and is most applicable in the technology-based arena (Chen et al., 2015). This ability is closely related to the founding entrepreneur's own knowledge base, as well as the knowledge and skills that can be accessed through networks (Chen et al., 2015; Huggins \& Thompson, 2015).

Quite often, because of financial constraints, the only resources, apart from the entrepreneur's own knowledge base, entrepreneurial businesses readily have access to are human and social capital in the form of social networks. Networks are therefore important elements of any entrepreneurial business's social capital (Hayter, 2016; Leyden, Link, \& Siegel, 2014). These resources are critical, especially during the initial development period of the business. Although the ability of entrepreneurial businesses to create value is determined by the quality of their human and social capital, the decisionmaking orientation to deploy these limited resources also plays an important role (Perry, Chandler, \& Markova, 2012). The use and relevance of predictive and/or non-predictive decision-making orientations for value creation, as well as the role of networks in TBEBs, has however not been extensively researched and needs further investigation (Shepherd, Williams, \& Patzelt, 2015).

In large businesses, decision-making is often a collective operation with ample supporting resources to achieve optimal results (Sarasvathy, 2008, p. 93). In entrepreneurial businesses, which are usually smaller enterprises, decisions have to be made by an individual entrepreneur without the supporting resources found in larger businesses, and the process is often influenced by biases and heuristics (Dew, Read, \& Wiltbank, 2008; Miane, Soh, \& Dos Santos, 2015). Effective decision-making ultimately determines the strategic course, as well as the eventual survival and growth of the business (Dew et al., 2008; Shepherd et al., 2015). The adoption of an appropriate decision-making orientation has therefore a detrimental impact on the perceived value that is being created.

\section{Objective of research}

Given the importance of TBEB, the purpose of this study is to identify how networks can contribute to value creation in these businesses, taking into account the decision-making orientation adopted by the entrepreneurial team. The contribution of these findings is threefold: firstly, to contribute to a better understanding of value creation in TBEB; secondly, to develop recommendations for managing networks as an important resource in technology-based businesses, and enhancing the likelihood of value creation in these businesses; and, thirdly, to add to the body of knowledge of decision-making in general and TBEB in particular by developing and empirically investigating a hypothesised model depicting how networks and the decision-making orientation of the business influence the perceived value creation of TBEB.

\section{Literature overview and development of hypotheses}

The research gap that has been identified deals with value creation, networking and decision-making orientation in entrepreneurial businesses by innovative and technically minded entrepreneurs. The focus of this study is therefore on entrepreneurship and how it manifests itself in TBEB.

\section{Technology-based entrepreneurial businesses}

Technology-based entrepreneurial businesses are distinguished from other entrepreneurial businesses in that they make use of some or other form of technical expertise or process, which forms the basis for the business's existence. The adoption of the latest developments in a business's area of expertise is a fundamental characteristic of these businesses. While it is challenging to differentiate between TBEB and other types of entrepreneurial businesses, Kile and Phillips (2009, p. 45) use the North American Industry Classification System (NAICS), Global Industry Classification System (GICS) and the Standardised Industry Classification (SIC) codes to separate those industrial activities that can be described as technology based. The following technologies form the core of what can be classified as technology-based activities: computer hardware manufacturing, software development, medical technology, communication equipment and services, electronics manufacturing, Internet and other information technology (IT) services (Kile \& Phillips, 2009, p. 45).

Technology-based entrepreneurial businesses can also be identified by people who play a leading role in these businesses. Engineers, life and physical scientists, mathematics specialists, engineering and science technicians and computer specialists are commonly identified as the persons involved in the start-up and development of TBEBs (Audretsch et al., 2015; Moutinho, Au-Yong-Oliviera, Coelho, \& Manso, 2016). Technology-based entrepreneurial businesses are also characterised by high levels of appropriate technical knowledge, which, in the case of small entrepreneurial businesses, is normally concentrated in one or two of the founding entrepreneurs. Various studies have identified the knowledge base of technology-based industries as their most important identifiable characteristic (Hayter, 2016; Moutinho et al.).

Therefore, TBEBs, for the purpose of this study, refer to entrepreneurial businesses which operate in the field of engineering and information technology, that are mainly constituted around the knowledge base of the entrepreneur and in which creating and recognising opportunities, selfevaluation and innovation, and managing resources play an important role. 
Dependent variable: Perceived value creation in technology-based entrepreneurial businesses

Hlady-Rispal and Servantie (2018) described the value creation process as a key component of entrepreneurship, which focuses mostly on the actions of the entrepreneurial team and the innovative ways in which they create value with very limited resources at their disposal. The value that is created in the process can be measured in both financial and non-financial terms. The financial side consists mainly of the profit that is generated, as well as the generation of financial wealth, while the non-financial side is dominated by the effect on the people in the business. This view concurs with that of earlier researchers like Lepak, Smith and Taylor (2007), as well as Tantalo and Priem (2014), who posited that the value creation process includes actions such as knowledge creation, motivation and training. Non-financial value is also created in the form of unique competencies and efficiencies, which serve as a catalyst for further value creation (Lepak et al., 2007). These competencies often turn into passions, which can be described as experiences of intense positive feelings (Cardon, Gregoire, Stevens, \& Patel, 2013). Entrepreneurial teams in general are motivated by their passion for inventing new products or services, as well as their passion for founding new businesses and developing these businesses into organisations that supply new products and services. This leads to value creation for the customer and the entrepreneurial business and eventually provides the business with a competitive advantage, which is very hard to imitate (Demil, Lecocq, Ricart, \& Zott, 2015).

\section{Independent variables: Social capital in the form of structured and unstructured networks}

Technology-based entrepreneurial businesses are often characterised by a shortage of resources, especially during the beginning phases of the business. The most important resources for these businesses are the human and social capital available to them (De Massis, Audretsch, Uhlaner, \& Kammerlander, 2018), which provide the core competencies of the business.

Social capital can be described as the goodwill that exists between individuals or groups and is a valuable resource to enhance co-operation between stakeholders and to foster norms and traditions (Stam, Arzlanian, \& Elfring, 2014). Various researchers in their empirical studies have cited networks as a major and important component of social capital (Hmieleski, Carr, \& Baron, 2015, p. 295; Stam et al., 2014, p. 154).

Networks are relationships that are formed, both internally and externally, by the business and other stakeholders during its normal operations. Networks are important as they provide the business with access to additional resources and, eventually, to value creation (Baker, Grinstein, \& Harmanciogla, 2015; Felzensztein, Ciravegna, Robson, \& Amoros, 2015). These networks can be structured or unstructured in nature (Baker et al., 2015; Felzensztein et al., 2015). Structured networks are often formed between entrepreneurial businesses and their customers, suppliers and other stakeholders (Chowdhury, 2011; Ritter \& Walter, 2012). Structured networks in TBEB refer to regular organised contacts between the employees of the business and its network partners. These contacts include the identification of possible and suitable network partners, an analysis of what to achieve with each network partner and discussions on how to support each other to achieve success. These networks are much more formal than the informal social networks and have specific shared goals in mind. Unstructured networks refer to regular informal social contacts between employees of the business and suppliers, customers, business colleagues inside the business, and other entrepreneurs and technical colleagues outside the business.

\section{Mediating variable: Decision-making orientation}

The decision-making orientation of a business refers to a central behaviour pattern or approach to decision-making that permeates all levels of the business (Engelen, Gupta, Strenger, \& Brettel, 2015; Werhahn \& Brettel, 2012). When the subdimensions of the different decision-making approaches are applied throughout the organisation, a certain decisionmaking orientation develops, which plays an influential role in the value creation process. This study researches the relationship between the decision-making orientation adopted in the business and value creation, as well as other influencing factors such as structured and unstructured networks. This approach towards decision-making plays a mediating role when deploying the resources of the business. Two dimensions of decision-making orientation will be focused on, namely causal decision-making and effectual orientations.

A causal or rational decision-making orientation can be prevalent in a business with subdimensions of goals, resource acquisition, contingency avoidance and prediction (Durand \& Vaara, 2009; Yang \& Gabrielsson, 2017). The dimension goals entail the setting of goals that will ultimately be used to direct and focus decisions. Resource acquisition refers to directing decisions at acquiring the necessary resources to achieve the goals that have been set. Contingency avoidance is the conscious avoidance of contingencies by taking precautionary measures and decisions to limit or eliminate contingencies through elaborate research and analysis. The dimension prediction refers to the favouring of predicting the future through market analysis in order to provide concrete goals. A causal decision-making orientation is in other words heavily dependent on the ability to predict the future (Yang \& Gabrielsson, 2017).

Contrary to the causal or rational decision-making orientation, Werhahn and Brettel (2012) proposed a behavioural orientation of effectuation, which takes place on the organisational level, rather than on an individual level, and refer to it as effectual orientation. The subdimensions of an effectual orientation are means, partnerships, affordable loss, contingency and control. The first dimension, means, refers to the prominent role the available resources play in the decision-making process. The second dimension, 
partnerships, refers to the willingness of decision-makers to enter into partnerships with external stakeholders in order to expand the available resources to provide goods and services. The third dimension, affordable loss, refers to the underlying prerequisite in the decision-making logic that only those resources that the firm can afford to lose will be risked on the development of a new service or product. The fourth dimension, contingency, refers to the attitude of the decisionmaker towards contingencies. Decision-making is influenced by the decision-maker's willingness to deal with or avoid contingencies. The final dimension, control, refers to the decision-maker's ability to persuade the environment to accept what the entrepreneur has to offer (Dew, Read, Sarasvathy, \& Wiltbank, 2009; Engelen et al., 2015). Effectuation is most effective in uncertain business environments, like in the case of many TBEBs, where prediction is difficult or extremely costly.

\section{Hypotheses development}

Based on the discussion above, as well as a study of previous empirical research to support the development of a particular hypothesis, a number of hypotheses were developed.

\section{Networks and perceived value creation}

In a study based on the global entrepreneurship monitor data of 36 countries, Kwon and Arenius (2010) found that there is a positive correlation between structured and unstructured networks and opportunity recognition, as well as between structured and unstructured networks and entrepreneurial value creation on business level. In another study amongst 159 independent sales contractors and 71 top executives of high-technology businesses, Baron and Markman (2003) found that the higher the entrepreneurs' networking capabilities, the greater their financial success, and the more value they create for their respective businesses. Similar results were found by Walter, Auer and Ritter (2006) amongst 247 technology-based small to medium-sized businesses in Germany, and Chowdhury (2011) in a study involving 723 young businesses (less than 6 years in existence), when a direct relationship between revenue growth and networks with customers was established. Therefore, it is hypothesised that:

$\mathbf{H}^{1 \mathrm{a}}$ : There is a positive relationship between structured networks and perceived value creation in TBEB.

$\mathbf{H}^{\mathbf{1 b}}$ : There is a positive relationship between unstructured networks and perceived value creation in TBEB.

\section{Structured and unstructured networks and decision- making orientation}

In the process of acquiring and deploying resources like structured and unstructured networks, the decision-making orientation that entrepreneurial businesses adopt is influenced by the networks available to TBEB. These networks provide TBEB with additional resources to satisfy market needs or to influence the market to accept the goods and services available to TBEB through its network partners (Sarasvathy, 2001; Stam et al., 2014). A causal decision-making orientation can be adopted if adequate information is available on which to effectively base decisions and network partners are selected accordingly. However, in the absence of sufficient information and market uncertainty, networks are used to create a market need based on the competencies accessible through structured and unstructured networks (Makridakis, Hogarth, \& Gaba, 2009). Studies conducted by Dew et al. (2009), Rasmussen, Mosey and Wright (2015), Hayter (2016) and Baker et al. (2015) have all found positive relationships between structured networks and unstructured networks and the businesses's decision-making orientation.

Based on the discussions above, therefore it is hypothesised that:

$\mathbf{H}^{2 a}$ : There is a positive relationship between structured networks and the decision-making orientation adopted by TBEB.

$\mathbf{H}^{2 \mathrm{~b}}$ : There is a positive relationship between unstructured networks and the decision-making orientation adopted by TBEB.

\section{Decision-making orientation and perceived value creation}

The decision-making orientation adopted by a business has a direct influence on the perceived value creation of the business (Brettel, Mauer, Engelen, \& Küpper, 2012; Werhahn \& Brettel, 2012, p. 10). Brettel et al. (2012) have found a positive relationship in their research on the influence of an effectual decision-making orientation on the R\&D performance of projects undertaken in larger businesses. Similarly, Werhahn and Brettel (2012) have found empirical evidence of a positive relationship between effectual orientation by the entrepreneurial business and business performance, which plays an important role in the perception of value creation. Brinckmann, Grichnik and Kapsa (2010), in their metaanalysis of the effect of a more predictive decision-making orientation on value creation, found strong evidence of a positive relationship between a causal decision-making orientation and value creation in small new businesses (Brinckmann et al., 2010, p. 36; Dew et al., 2009). Based on the empirical evidence presented above, the following hypothesis is formulated:

$\mathbf{H}^{3}$ : There is a positive relationship between the decision-making orientation adopted by the business and the perceived value creation in TBEB.

\section{Mediating role of decision-making orientation adopted}

In any active process it often happens that an intervention occurs between stimulus and response. If this intervention influences the effects of stimuli on behaviour, the relationship between stimuli and behaviour is said to be mediated by the intervening process (Baron \& Kenny, 1986). In other words, in a business sense, a mediating variable is an action or process in an organisation that intervenes between the independent variables and the dependent variables. In her seminal work on the development of the concept of effectuation, Sarasvathy (2001) asserts that the decision-making logic followed by an entrepreneur plays an intervening or mediating role when deploying resources. She shows that experienced entrepreneurs tend to adopt an effectual approach towards 
decision-making under conditions of high environmental uncertainty. Similarly, Dew et al. (2009) have found that in the absence of uncertainty, a decision-making orientation based on causation is adopted when making use of business networks and the deployment of resources, while creating value for the business. A number of more recent studies have confirmed the prevalence of effectuation as a preferred decision-making logic in entrepreneurial businesses and start-ups and the mediating role it plays between structured and unstructured networks and perceived value creation (Kalinic, Sarasvathy \& Forza, 2014; Miane et al., 2015; Nummela, Saarankertho, Jokela \& Loane, 2014).

Based on the empirical evidence presented above, the following hypothesis is formulated:

$\mathbf{H}^{4}$ : The decision-making orientation adopted by the business plays a mediating role between the structured and unstructured networks and the perceived value creation in TBEB.

The above hypotheses are presented in Figure 1.

\section{Sampling procedure and response rate}

The hypothesised model (see Figure 1) was empirically tested amongst TBEBs operating mainly in the engineering and information technology spheres of business. For the purpose of this study, a convenience snowball sampling was used. The sampling was initiated by using the business directories of the bigger industrial areas, as well as identifying possible respondents from the website of AfriSeek.com (2013). Once identified, suitability and willingness to participate in the study were confirmed telephonically, details were captured on a database and the respondents were requested to identify other TBEBs who could be approached to participate in this study. These potential respondents were then also contacted telephonically and the process was repeated. To ensure that an even distribution of new and older businesses was included in the sample, the respondents were also asked during the first telephonic contact to indicate the number of years they had been in operation since inception. The sample size was increased until an almost equal distribution of new and old businesses was obtained. The sampling technique and methodology are consistent with the techniques employed by other entrepreneurship researchers who have been constrained by the lack of a national database of entrepreneurial businesses (Farrington, 2009, p. 335; Kariv, 2012, p. 174).

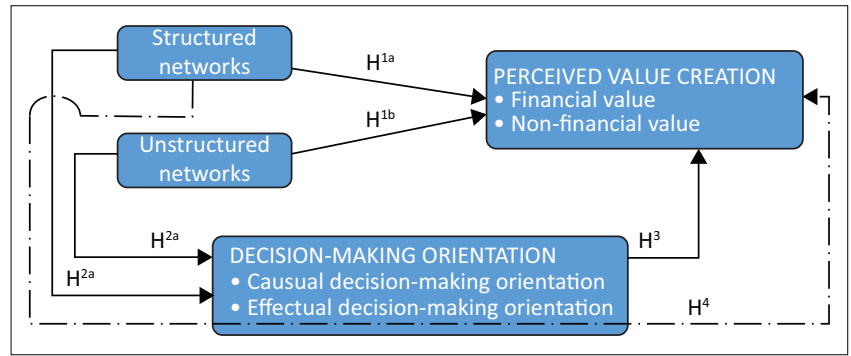

FIGURE 1: Proposed hypothesised model.
The sampling technique and procedure followed, resulted in the identification of 2382 potential TBEBs. A total of 313 usable questionnaires were received from the respondents.

\section{Scale development and operationalisation}

Several studies (see Table 1) were consulted to identify items measuring the dependent, independent and mediating variables in this study. Based on the scales developed, the variables were operationalised (see Table 1). A selfadministered structured questionnaire was distributed to potential respondents via email, which provided them with a link to complete the questionnaire online. The items referred to in the questionnaire are listed in Appendix 1.

\section{Data analysis}

The data collected from 313 usable questionnaires were subjected to various statistical analyses. An exploratory factor

TABLE 1: Scales measuring perceived value creation, structured and unstructured networks and decision-making orientation.

\begin{tabular}{|c|c|c|c|}
\hline Variable & Operationalisation & Items & Sources \\
\hline $\begin{array}{l}\text { Perceived value } \\
\text { creation (financial } \\
\text { dimension) }\end{array}$ & $\begin{array}{l}\text { Refers to the perception of the } \\
\text { entrepreneur about whether } \\
\text { the business's growth in terms } \\
\text { of turnover and number of } \\
\text { employees, profitability, } \\
\text { cash flow and ability to } \\
\text { invest in valuable assets has } \\
\text { increased over the last } 2 \text { years } \\
\text { of operating the technology- } \\
\text { based business. }\end{array}$ & 6 & $\begin{array}{l}\text { Chandler and } \\
\text { Hanks (1993); } \\
\text { Venter, Farrington } \\
\text { and Boshoff (2012) }\end{array}$ \\
\hline $\begin{array}{l}\text { Perceived value } \\
\text { creation } \\
\text { (non-financial } \\
\text { dimension) }\end{array}$ & $\begin{array}{l}\text { The non-financial dimension } \\
\text { of perceived value creation } \\
\text { refers to the job satisfaction } \\
\text { the entrepreneur and the } \\
\text { entrepreneurial team experience, } \\
\text { as well as the strategic } \\
\text { competencies and efficiencies } \\
\text { that are being developed in } \\
\text { the business. }\end{array}$ & 17 & $\begin{array}{l}\text { Obloj, Obloj and } \\
\text { Pratt (2010); Peng, } \\
\text { Schroeder and } \\
\text { Shah (2008) }\end{array}$ \\
\hline $\begin{array}{l}\text { Structured } \\
\text { networks }\end{array}$ & $\begin{array}{l}\text { Refers to those regular formal } \\
\text { (structured) interactions by } \\
\text { employees of the business with } \\
\text { other individuals both within } \\
\text { and outside the business. These } \\
\text { structured networks contribute } \\
\text { to the effective functioning of } \\
\text { business operations as they } \\
\text { provide access to additional } \\
\text { resources. }\end{array}$ & 5 & $\begin{array}{l}\text { De Carolis, Litzky } \\
\text { and Eddlestone } \\
\text { (2009); Walter } \\
\text { et al. (2006) }\end{array}$ \\
\hline $\begin{array}{l}\text { Unstructured } \\
\text { networks }\end{array}$ & $\begin{array}{l}\text { Refers to informal (unstructured) } \\
\text { interactions by employees of the } \\
\text { business with other individuals } \\
\text { both within and outside the } \\
\text { business. These unstructured } \\
\text { networks contribute to the } \\
\text { effective functioning of business } \\
\text { operations as they provide access } \\
\text { to additional resources. }\end{array}$ & 5 & $\begin{array}{l}\text { Jones and } \\
\text { Jayawarna (2010); } \\
\text { Presutti, Boari and } \\
\text { Fratocchi (2007) }\end{array}$ \\
\hline $\begin{array}{l}\text { Decision-making } \\
\text { orientation (causal } \\
\text { dimension) }\end{array}$ & $\begin{array}{l}\text { Refers to that dimension of the } \\
\text { decision-making orientation } \\
\text { which focuses mainly on } \\
\text { expected returns, as well as } \\
\text { comprehensive planning and } \\
\text { analysis. Great emphasis is also } \\
\text { placed on predicting the future } \\
\text { as accurately as possible and } \\
\text { formulating clear goals. }\end{array}$ & 9 & $\begin{array}{l}\text { Brettel et al. } \\
(2012) ; \text { Dew et al. } \\
(2009) ; \text { Sarasvathy } \\
(2001)\end{array}$ \\
\hline $\begin{array}{l}\text { Decision-making } \\
\text { orientation } \\
\text { (effectual } \\
\text { dimension) }\end{array}$ & $\begin{array}{l}\text { Refers to that dimension of the } \\
\text { decision-making orientation } \\
\text { which focuses mainly on the } \\
\text { resources and means available to } \\
\text { conduct business operations } \\
\text { while limiting risks to an } \\
\text { affordable loss. Emphasis is also } \\
\text { placed on partnerships, creating } \\
\text { opportunities, controlling the } \\
\text { environment and managing } \\
\text { contingencies. }\end{array}$ & 13 & $\begin{array}{l}\text { Brettel et al. } \\
\text { (2012); Dew et al. } \\
\text { (2009); Sarasvathy } \\
\text { (2001); Werhahn } \\
\text { and Brettel (2012) }\end{array}$ \\
\hline
\end{tabular}


analysis (EFA) was performed on all the items in order to identify the unique factors in the data. Only factors having a value of 0.5 or higher were considered (Hair, Black, Babin, Anderson, \& Tatham, 2006, p. 777). Bartlett's test of sphericity was performed to establish the factor analysability of the data. A principal component analysis with a varimax rotation was specified as the extraction and rotation method for cases where factors were not expected to be correlated. When correlation of factors was expected, principal axis factoring with an oblique rotation was specified as the extraction and rotation method. No restriction on the number of factors was specified, and Kaiser's rule (eigenvalues greater than 11) was used to determine the number of factors (Cliff, 1988, p. 276). After the factor analysis was completed, all items with a factor loading of lower than 0.5 were removed from the factor loading analysis results. Items loading together onto one factor with a factor loading of 0.5 or higher were grouped together. Finally, reliability of the factors assessed in the measuring instrument was determined by calculating Cronbach's alpha coefficients to evaluate the internal consistency between the items measuring each construct in the theoretical model.

Structural equation modelling was used to evaluate the relationships amongst the variables, using the computer programmes Statsoft Incorporated (2011), Statistica (Version 10) and IBM SPSS AMOS (Version 21.0.0). Finally the 'goodness-offit' of the model was assessed using various fit indices, like the Satorra-Bentler scaled chi-square $\left(\chi^{2}\right)$, the normed chi-square and the root mean square error of approximation (RMSEA), as well as the $90 \%$ confidence interval for RMSEA.

\section{Empirical results Demographic information}

The information collected from the demographic questions pertaining to each of the 313 usable questionnaires can be summarised as follows: the majority of the respondents $(88.2 \%)$ were from the engineering and IT industries. The entrepreneurs surveyed have been in business for quite some time, with $30.7 \%$ indicating that they have been in business between 9 and 20 years and 48.5\%having been in business for more than 20 years. Almost one-third of the respondents (34.5\%) indicated that they employed more than 50 employees, and $20.1 \%$ reported to have employed less than 6 employees. The vast majority of the respondents (76.3\%) were between 31 and 60 years of age, with $96.2 \%$ of the entrepreneurs indicating that they have post-school qualifications. Of the respondents, $64.9 \%$ have started more than two businesses in their career.

\section{Factors identified during the exploratory factor analyses}

Seven factors were identified from the EFA: financial value (FinV), job-satisfaction and independence (JSat), innovation (Inno), causal decision-making orientation (CaDMO), co-create the future (CoFut), structured networks (StNet) and unstructured networks (UnsNet).

As all the items for structured networks and unstructured networks loaded onto these two constructs as expected, the operationalisation of the constructs StNet and UnsNet remained unchanged as shown in Table 1.

All six items in the financial dimension of perceived value creation loaded onto one factor as expected. Of the 17 items measuring the non-financial dimension of the construct perceived value creation, six items loaded together onto one factor JSat, while 5 of the remaining 11 items loaded together on another factor to be named Inn. As a result of the factor analysis, perceived value creation was thus split into three separate constructs namely: Financial value (FinV), Jobsatisfaction and independence (JSat) and Innovation (Inno). Financial value (FinV) refers to the perception of the entrepreneur about whether the business's growth in terms of turnover and number of employees, profitability, cash flow and ability to invest in valuable assets had increased over the last 2 years of operating the technology-based business. Jobsatisfaction and independence, refers to the extent to which entrepreneurs and their teams experienced their work as rewarding, enjoyable and fulfilling. It also refers to the enjoyment of working with their colleagues and operating independently. Innovation (Inno), refers to the non-financial value created when entrepreneurs and their teams experiment with innovative ideas for new products, services, processes and procedures, as well as searching for opportunities to learn and improve, especially from people outside the business, while being free from the restraints of large business organisations.

Of the 22 items included in the final questionnaire to measure the construct decision-making orientation, nine items loaded together onto one factor, causal decision-making orientation (CaDMO), and another four loaded together onto another factor, co-create the future (CoFut). As a result, the operationalisation of the factor decision-making orientation was split into two. Causal decision-making orientation refers to that dimension of the decision-making orientation which focuses mainly on the business having a clear vision of the future while being able to make decisions based on causal reasoning. Co-create the future refers to the propensity of entrepreneurs and their teams to engage with partners to actively influence business trends and shape the business environment to suit their businesses.

\section{Validity and reliability assessments}

The validity of the instrument used in this study was assessed using the EFA results. Convergent, discriminant and face validity were the components used in the assessment of validity. Convergent validity was assessed by using the variance extracted (VE) for each factor. A VE of 0.50 or higher indicates adequate evidence of convergence (Hair, Ringle \& Sarstedt, 2011:146). The VE for each factor is presented in Table 2.

Discriminant analysis was assessed by comparing the square of the correlation estimates between any two factors with the VE of the two factors. If the VE value was found to be greater than 0.5 , it indicates that the discriminant validity is adequate 
(Hair et al., 2011:146). All VEs in this study were found to be greater than the square of the correlation estimates; therefore, discriminant validity was deemed adequate. Face validity was shown through the theoretical conceptualisation of this study, indicating the face validity was adequate.

From the factor analysis and the subsequent identifications of new constructs, the following hypotheses were formulated and empirically tested during SEM:

$\mathbf{H}^{1 \mathrm{a}}$ : There is a positive relationship between the structured networks of the business and the financial value created by a technology-based entrepreneurial business.

$\mathbf{H}^{\mathbf{1 b}}$ : There is a positive relationship between the structured networks of the business and the job satisfaction and independence experienced by the entrepreneurial team of a technology-based entrepreneurial business.

$\mathbf{H}^{1 \mathrm{c}}$ : There is a positive relationship between the structured networks of the business and innovation value created in a technology-based entrepreneurial business.

$\mathbf{H}^{2 a}$ : There is a positive relationship between the unstructured networks of the business and the financial value created by a technology-based entrepreneurial business.

$\mathbf{H}^{2 \mathbf{b}}$ : There is a positive relationship between the unstructured networks of the business and the job satisfaction and independence experienced by the entrepreneurial team of a technology-based entrepreneurial business.

$\mathbf{H}^{2 c}$ : There is a positive relationship between the unstructured networks of the business and innovation value created in a technology-based entrepreneurial business.

$\mathrm{H}^{3 \mathrm{a}}$ : There is a positive relationship between the structured networks of the business and the causal decision-making orientation adopted by a technology-based entrepreneurial business.

$\mathbf{H}^{3 \mathrm{~b}}$ : There is a positive relationship between the structured networks of the business and co-creating the future by a technology-based entrepreneurial business.

$\mathbf{H}^{\text {4a }}$ : There is a positive relationship between the unstructured networks of the business and the causal decision-making orientation adopted by a technology-based entrepreneurial business.

$\mathbf{H}^{4 \mathrm{~b}}$ : There is a positive relationship between the unstructured networks of the business and co-creating the future by a technology-based entrepreneurial business.

$\mathbf{H}^{5 a}$ : There is a positive relationship between the causal decisionmaking orientation adopted and the financial value created by a technology-based entrepreneurial business.

$\mathbf{H}^{\mathbf{5 b}}$ : There is a positive relationship between the causal decisionmaking orientation adopted and the job satisfaction and

TABLE 2: Cronbach's alpha coefficients and variance extracted of all factors.

\begin{tabular}{lcc}
\hline Factor & Cronbach's alpha (reliability) & VE \\
\hline Financial value (FVal) & 0.934 & 0.698 \\
Job-satisfaction and independence (JSat) & 0.927 & 0.635 \\
Innovation (Inno) & 0.827 & 0.448 \\
Unstructured networks (UnsNet) & 0.869 & 0.516 \\
Structured networks (StNet) & 0.938 & 0.683 \\
Causal decision-making orientation (CaDMO) & 0.959 & 0.672 \\
Co-create the future (CoFut) & 0.855 & 0.511 \\
\hline
\end{tabular}

$\mathrm{VE}$, variance extracted. independence experienced by the entrepreneurial team of a technology-based entrepreneurial business.

$\mathbf{H}^{5 \mathrm{c}}$ : There is a positive relationship between the causal decisionmaking orientation adopted and innovation value created in a technology-based entrepreneurial business.

$\mathbf{H}^{6 a}$ : There is a positive relationship between the propensity to co-create the future in the business and the financial value created by a technology-based entrepreneurial business.

$\mathbf{H}^{6 \mathbf{b}}$ : There is a positive relationship between the propensity to co-create the future in the business and the job satisfaction and independence experienced by the entrepreneurial team of a technology-based entrepreneurial business.

$\mathbf{H}^{6 \mathrm{cc}}$ : There is a positive relationship between the propensity to co-create the future in the business and innovation value created in a technology-based entrepreneurial business.

$\mathbf{H}^{7}$ : The decision-making orientation adopted by the business plays a mediating role between the structured and unstructured networks and the financial value, job satisfaction and independence and innovation in TBEB.

\section{Descriptive statistics and correlations}

Descriptive statistics were calculated from the sample data (see Table 3).) The responses to the items were ranked on a 7-point Likert scale ranging from strongly disagree (1) to strongly agree (7).

Most of the respondents agreed with the statements measuring the different variables. This agreement varied between $54.58 \%$ for financial value to $93.97 \%$ for structured networks. The lowest mean score calculated from all 313 responses was that of unstructured networks (4.782), while the highest mean score was that of innovation (5.697).

The Pearson's product moment correlation was calculated and reviewed to assess whether there is a relationship between two or more factors. With the exception of causal decision-making orientation, all other factors have significant $(p<0.05)$ correlations with each other, varying from moderate to strong relationships. Causal decision-making orientation has moderate correlations with structured networks, with no significant relationships with the other factors.

The strongest correlation reported is that between innovation and job satisfaction and independence $(r=0.638)$. This can be expected as both these constructs include items that have to do with independent thinking and enjoyment of the work experience.

TABLE 3: Descriptive statistics and correlations of the dependent, independent and mediating variables.

\begin{tabular}{lcccccc}
\hline Factor & Mean & SD & Disagree (\%) & Neutral (\%) & Agree (\%) & N/A (\%) \\
\hline FinV & 4.581 & 1.797 & 30.09 & 11.98 & 54.58 & 3.35 \\
JSat & 5.633 & 0.992 & 4.75 & 11.02 & 81.63 & 2.60 \\
Inno & 5.697 & 1.002 & 5.35 & 10.38 & 80.83 & 3.43 \\
UnsNet & 4.782 & 1.242 & 7.57 & 9.68 & 79.71 & 3.04 \\
StNet & 5.358 & 1.194 & 1.20 & 3.71 & 93.97 & 1.12 \\
CaDMO & 5.168 & 1.480 & 9.78 & 10.03 & 74.19 & 6.01 \\
CoFut & 4.957 & 1.218 & 18.53 & 19.30 & 58.21 & 3.96 \\
\hline
\end{tabular}

FinV, financial value; JSat, job satisfaction and independence; Inno, innovation; UnsNet, unstructured networks; StNet, structured networks; CaDMO, causal decision-making orientation; CoFut, co-create the future; SD, standard deviation; N/A, not applicable. 


\section{Structural equation modelling}

The main analysis conducted in this study was SEM. It was used to determine the model of best fit for the hypothesised relationships. Structural equation modelling was also used to determine the mediating effect of decision-making orientation on the relationship between the independent and dependent variables.

The model of best fit was obtained by excluding insignificant relationships (see Figure 2). The goodness-of-fit indices and the parameter estimates are presented in Tables 4 and 5, respectively.

From Figure 2 and Table 5, it can be seen that structured networks is positively related $(0.285, p<0.001)$ to co-create the future (hypothesis $\mathrm{H}^{3 b}$ ). In other words, the more structured networks a business is involved in, the more it would adopt a decision-making orientation of co-creating the future. Structured networks were also found to be positively related (0.273, $p<0.001)$ to causal decision-making orientation (hypothesis $\mathrm{H}^{3 \mathrm{a}}$ ). In other words, the more structured networks a business is involved in, the more it would adopt a causal decision-making orientation. This means that both co-create the future and causal decision-making orientation are positively related to structured networks, which indicates that the more structured networks a business enters into, the more it would make use of either predictive or non-predictive decision-making orientations.

Unstructured networks is positively related $(0.322, p<0.001)$ to co-creating the future (hypothesis $\mathrm{H}^{4 \mathrm{~b}}$ ). This suggests that as interaction between the entrepreneurial team and other informal or social groupings increases, the co-creation orientation would be strengthened in TBEB.

Co-creating the future is positively related to financial value $(0.712, p<0.001)$ (hypothesis $\left.\mathrm{H}^{6 \mathrm{a}}\right)$, job satisfaction and independence $\left(0.456, p<0.001\right.$ ) (hypothesis $\mathrm{H}^{6 \mathrm{~b}}$ ) and innovation $(0.542, p<0.001)$ (hypothesis $\left.\mathrm{H}^{6 c}\right)$. This means that TBEBs with higher co-creating the future orientation would be more likely to increase their wealth and financial benefits, while also enhancing the job satisfaction and feelings of independence and innovation of the entrepreneurial team.

The relationship between causal decision-making orientation and financial value $(-0.155, p=0.058)$ (hypothesis $\mathrm{H}^{5 \mathrm{a}}$ ) falls just outside the $5 \%$ level of significance and was therefore not regarded as significant. In other words, these findings suggest that it does not seem likely that by adopting a causal decisionmaking orientation, the financial value-creation of TBEBs would be increased.

The following hypotheses were rejected as no significant relationships could be established between the constructs: structured networks and financial value $\left(\mathrm{H}^{1 \mathrm{a}}\right)$, structured networks and job satisfaction and independence $\left(\mathrm{H}^{1 \mathrm{~b}}\right)$, structured networks and innovation $\left(\mathrm{H}^{1 \mathrm{c}}\right)$, unstructured networks and financial value $\left(\mathrm{H}^{2 \mathrm{a}}\right)$, unstructured networks and job satisfaction and independence $\left(\mathrm{H}^{2 \mathrm{~b}}\right)$, unstructured networks and innovation $\left(\mathrm{H}^{2 \mathrm{c}}\right)$, unstructured networks and causal decision-making orientation $\left(\mathrm{H}^{4 \mathrm{a}}\right)$, causal decision-making orientation adopted and the job satisfaction and independence $\left(\mathrm{H}^{5 \mathrm{~b}}\right)$, causal decision-making orientation and innovation $\left(\mathrm{H}^{5 c}\right)$.

\section{The mediating effect of decision-making orientation}

In order to show the mediating effect of a variable within a model, the following four steps were followed:

Firstly, the relationship between the independent variables structured networks (StNet) and unstructured networks (UnsNet) and the dependent variables financial value (FinV), innovation (Inno), and job satisfaction (JSat) were established and found to be as follows: StNet $\rightarrow$ Inno $(0.116, p<0.001)$, UnstNet $\rightarrow$ Inno $(0.496, p=0.045)$, UnstNet $\rightarrow$ FinV $(0.439, p<0.001)$ and UnstNet $\rightarrow$ JSat $(0.410, p<0.001)$. These values show that the relationships between the above variables are shown to be significant.

Secondly, the relationship between the independent variables (StNet and UnsNet) and the mediating variables co-create future (CoFut) and causal decision-making orientation (CaDMO) was established and found to be as follows: UnsNet $\rightarrow$ CoFut (0.300, $p<0.001)$, StNet $\rightarrow$ CaDMO (0.272, $p=0.001)$ and StNet $\rightarrow$ CoFut $(0.287, p<0.001)$. These values indicate that the relationships between the above variables are shown to be significant.

Thirdly, the correlation between the mediating variables and the dependent variables was established and found to be as follows: CoFut $\rightarrow$ FinV $(0.712, p<0.001)$, CoFut $\rightarrow$ JSat (0.456, $p<0.001)$, CoFut $\rightarrow$ Inno $(0.452, p<0.001)$ and CaDMO $\rightarrow$ FinV $(-0.115, p=0.058)$. These values show that the relationships between the mediating variables and dependent variables are significant. While the relationship between financial value and causal decision-making orientation is insignificant, using a 0.05 level, it is so close to the cut-off value that it can be deemed relatively significant.

Fourthly, the full model of relationships between the dependent, independent and mediating variables was tested. In full mediation, the relationship between the dependent variables and mediating variables should be significant, the relationship between the mediating variable and independent variables should be significant, while the direct relationship between the independent and dependent variables should be insignificant. This will indicate that the relationships between the dependent and independent variables are completely mediated by the mediating variables used in the model. For partial mediation, all the relationships will be significant; however, the direct relationship between the dependent and independent variables will be weaker or smaller when compared to the model assessed in the first step (Baron \& Kenny, 1986, p. 1178). From the results, one can infer that cocreate future (CoFut) fully mediates the relationships, while causal decision-making orientation (CaDMO) does not have a 


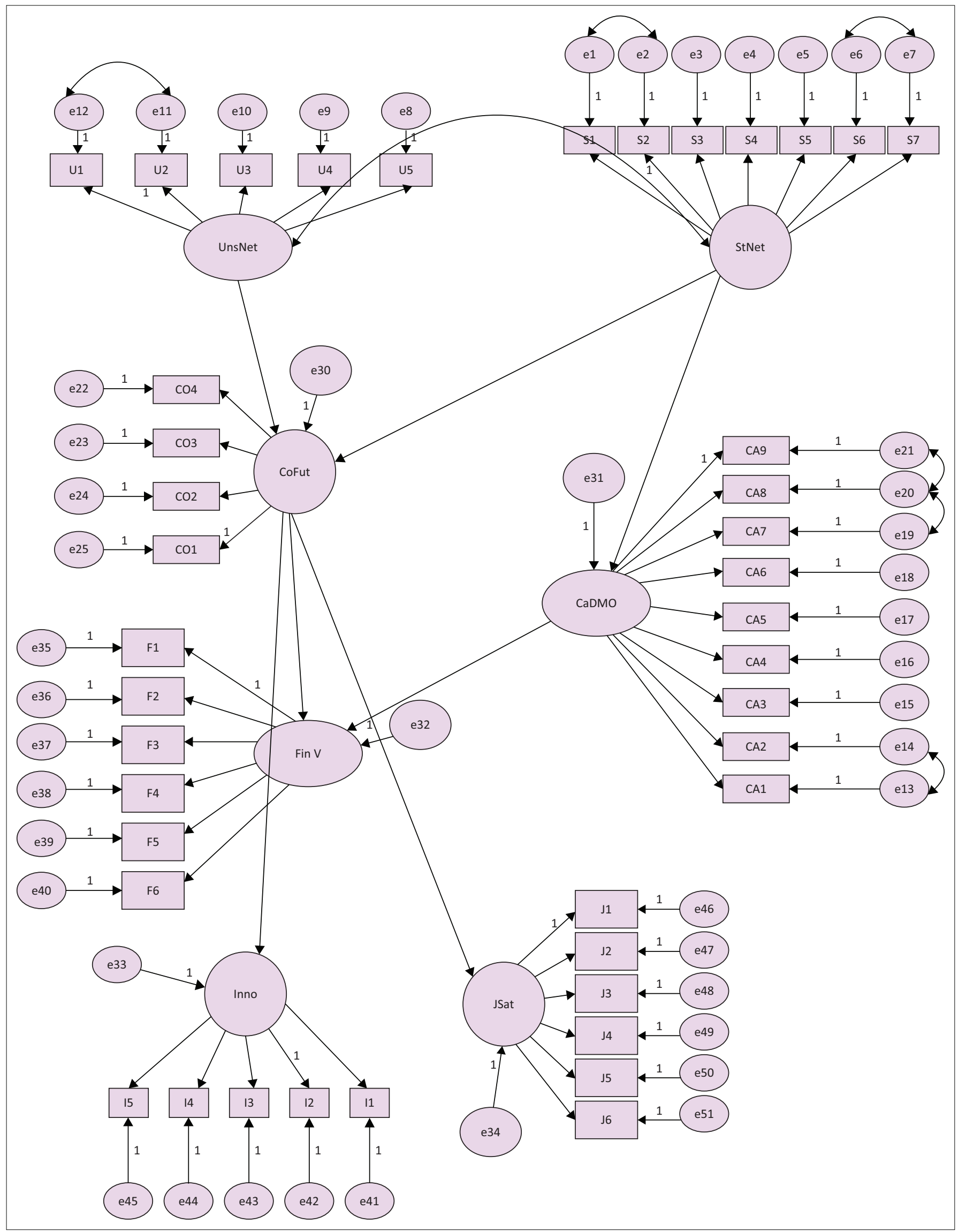

FIGURE 2: Structural equation modelling model. 
TABLE 4: Goodness-of-fit indices.

\begin{tabular}{lcc}
\hline Index & Norm & Results for model \\
\hline $\mathrm{CMIN} / d f\left(\chi^{2} / d f\right)$ & $<3.00$ & 2.302 \\
$\mathrm{CFI}$ & $>0.90$ & 0.910 \\
$\mathrm{TLI}$ & $>0.90$ & 0.903 \\
$\mathrm{RMSEA}$ & $<0.07$ & 0.065 \\
PGFI & The higher the better & 0.851 \\
\hline
\end{tabular}

CMIN/df, Chi square minimum discrepancy; CFI, comparative fit index; TLI, Tucker-Lewis index RMSEA, root mean squared error of approximation; PGFI, parsimony goodness-of-fit index.

TABLE 5: Parameter estimates with $p$-values.

\begin{tabular}{lcccc}
\hline Parameter & Estimate & SE & CR & $p$ \\
\hline CoFut $<---S t N e t$ & 0.285 & 0.050 & 5.690 & $*$ \\
CoFut<---UnsNet & 0.322 & 0.064 & 5.050 & $*$ \\
CaDMO<---StNet & 0.273 & 0.083 & 3.285 & 0.001 \\
FinV<---CoFut & 0.712 & 0.132 & 5.406 & $*$ \\
JSat<---CoFut & 0.456 & 0.081 & 5.649 & $*$ \\
Inno<---CoFut & 0.542 & 0.087 & 6.235 & $*$ \\
FinV<---CaDMO & -0.115 & 0.060 & -1.899 & 0.058 \\
\hline
\end{tabular}

$\mathrm{SE}$, standard error; $\mathrm{CR}$, construct reliability.

$*, p<0.001$.

mediating effect on the model. Hypothesis $\mathrm{H}^{7}$ is therefore accepted that co-create the future plays a mediating role between the independent and dependent variables.

\section{Discussion of results}

The findings confirm that the structured networks in which TBEBs engage are significantly related to a decision-making orientation of co-creating the future and causal decision-making orientation. These findings are to be expected as businesses generally use both these decision-making orientations, depending on the predictability of the environment. In other words, the more structured networks a business is involved in, the more it would adopt a decision-making orientation of co-creating future in uncertain environments or a causal decision-making orientation in more predictable environments. co-creating the future refers to the propensity of entrepreneurs and their teams to influence business trends, proactively design and shape the business environment in which they operate, while perceiving new entrants in the market as potential partners. Causal decision-making orientation refers to a decision-making orientation adopted when the business has a clear vision of the future while being able to make decisions based on causal reasoning. These finding are supported by studies conducted by Dew et al. (2009), Rasmussen et al. (2015), Hayter (2016) and Baker et al. (2015), who all confirm positive relationships between structured networks and effectual decision-making in unpredictable business environments. In stable and predictable environments, TBEBs will revert back to a causal decisionmaking orientation as supported by Rasmussen et al. (2015) and Hayter (2016) who all confirm positive relationships between structured networks and causal decision-making, in stable environments where the outcomes can be predicted. The type of decision-making orientation adopted by TBEBs when forming structured networks will therefore depend on the predictability of the environment. The process of forming structured networks includes the identification of possible and suitable network partners, an analysis of what to achieve with each network partner and discussions on how to support each other to achieve success. A further advantage of structured networks is that they often result in formal agreements between partners, which could be used to obtain operating finance.

The finding that unstructured networks is positively related cocreate the future is supported by the findings of prior research on the importance of unstructured networks and the impact on decision-making by Leyden et al. (2014) and Arregele et al. (2015).Unstructured networks are more prevalent in informal environments, which are mostly unpredictable. It is therefore quite understandable that TBEBs would tend to create a future by having regular contact with a wide array of people including other entrepreneurs with their own businesses, customers, suppliers and other business colleagues. However, the fact that unstructured networks do not influence value creation in this study is in contrast with previous research that found a positive relationship between the use of unstructured networks and values creation in TBEB (Kwon \& Arenius, 2010).

The findings further confirm that co-creating the future is positively related to financial value, job satisfaction and independence and innovation. This means that TBEBs with higher co-creating the future orientation would be more likely to increase their financial and non-financial value creation. Entrepreneurs in TBEB tend to be more satisfied with their jobs while they enjoy working for the business. They also find their work more rewarding and fulfilling while they enjoy working with their colleagues. The fact that they are not burdened by the organisational constraints of large businesses gives them a sense of independence and they tend to be quite innovative in their approach to find new and better services to offer their clients. These entrepreneurial teams like to stay abreast of new technologies and enjoy mastering these technologies in order to make the work easier and their products and services more valuable to their customers, while they also tend to be more innovative. This empirical finding echoes the findings of other researchers (Tantalo \& Priem, 2014; Werhahn \& Brettel, 2012) who have found empirical evidence of a positive relationship between effectual decision-making, business performance and innovation.

The findings of the study also support Sarasvathy's (2008) argument that the decision-making orientation of the entrepreneurial team plays a mediating role between resources and value creation. Adopting an effectual decisionmaking orientation creates more value from readily available resources like structured and unstructured networks, as co-creating the future constitutes a vital element of effectuation. Businesses should monitor the market to be alert to new competitors in the market. Once new entrants are identified, they should be perceived as potential partners by actively pursuing contact with them to identify mutually beneficial areas for co-operation. When a new project arises, the business should identify specific network partners for the project in advance to assist in meeting project targets. 
Network partners should be selected well in advance in order to negotiate joint outcomes. Businesses in general should select only those businesses that share the same broad vision and should choose only those network partners that are willing to make commitments based on future opportunities in the marketplace.

\section{Managerial implications}

As structured and unstructured networks have a significant relationship with the creation of both financial and nonfinancial values, these relationships should be nurtured and developed by the managerial team. Firstly, TBEB should do regular analyses of what vision it would like to strive for and then choose network partners according to the vision in order to create a shared vision with them. These network partners can be customers, suppliers or even competitors with complementary skills.

Secondly, when a new project arises, the business should identify specific network partners for the project in advance to assist in meeting project targets. Network partners should be selected well in advance in order to negotiate joint outcomes and allow stakeholders to create a shared vision for the future through co-creation. Technology-based entrepreneurial businesses should select only those businesses that share the same broad vision. Thirdly, business employees should be encouraged to make regular social contact with customers and suppliers by attending social functions, such as sporting events. These events can be arranged by the entrepreneurial business or the entrepreneurial team can partake in events organised by other parties. Management teams can also play a role to facilitate social contact for employees by the organising of social functions and celebrations of special occasions. They should also promote regular social contact with stakeholders outside the business, as well as other entrepreneurs, through memberships of business chambers, community forums and sports clubs.

Fourthly, businesses should take actions to influence business trends by developing unique and innovative features and uses of products and services, in collaboration with customers and suppliers. The entrepreneurial team should attempt to shape the business environment by proactively developing mutual goals with customers and suppliers. This can be done, for example, by developing environmentally friendly production processes or mutually beneficial training programmes for specialised employees. Businesses should monitor the market to be alert of new competitors in the market. Once new entrants are identified, they should be perceived as potential partners by actively pursuing contact with them to identify mutually beneficial areas for cooperation.

Finally, small businesses in general and TBEB in particular should pursue an effectual decision-making orientation focused on co-creating the future with other stakeholders in business environments that are not predictable. By co-creating the future instead of predicting the future, value is created by using the existing human and social capital resources available to the entrepreneur. The traditional decision-making model taught in business schools, which emphasises the importance of prediction and the compilation of comprehensive business plans, is not the only way to create value for entrepreneurial firms. This study shows that by adopting an effectual (co-creation) orientation, more perceived financial and non-financial value is created for technologically based entrepreneurial businesses, than following a causal or predictive approach, especially when prediction is difficult or impossible.

\section{Conclusion}

\section{Limitations of the study and recommendations for future research}

This study attempted to make a contribution to the entrepreneurship body of knowledge in general and TBEB in particular. However, as in all research, certain limitations inherent in the research design should be considered when making interpretations and conclusions with regard to the findings of this study. Therefore, the following limitations and recommendations are put forward for consideration in future entrepreneurial business research of this nature.

Although the empirical analysis of this study was based on a relatively large sample of 313 respondents, the use of snowball and convenience sampling does not always lead to representative samples (Zikmund, 2003, p. 380). The use of non-probability sampling introduces a source of potential bias into the study, and the findings cannot therefore be generalised to the general entrepreneurial population.

The data collected for this study depended on the reporting of organisational issues by individual respondents. The validity and reliability of the findings of this study could have been enhanced by including the perspectives of employees working in TBEBs. Answers to questionnaire items are in most cases limited to those of the founding entrepreneur completing the questionnaire. It is likely that different perspectives on some of the questions asked may exist within TBEBs and inclusion of these perspectives could prove useful.

Another limitation of this study is that it focuses only on a selected number of factors, considered as influencing the perception of value creation in technology-based businesses. Although these factors were selected during the literature review as being important, they are not the only ones that could have an influence on perceived value creation. However, these factors formed the focus of the research question in this study.

As TBEBs play a significant role in creating job opportunities, it could be useful to repeat this study in other countries in an attempt to verify to what extent the factors influencing perceived value creation in South African TBEBs differ from those affecting these businesses abroad. The question of whether cultural differences such as individualism versus 
collectivism influence the perception of value creation in TBEB would also be worth pursuing.

The cross-sectional design of surveys is a particular limitation, especially when it comes to measuring a construct like value creation, which is often a longitudinal construct. This means that because of lagged effects, actions taken when the survey is conducted will only affect value creation at a later stage. Qualitative research on the functioning of technology-based entrepreneurial ventures should also be included in future research to overcome this limitation.

Despite the limitations identified above, the results of this study contribute to, and reflect, existing theories. In addition, the potential opportunities for examining entrepreneurial teams in TBEB over a longer period of time through qualitative research hold considerable potential for future research.

\section{Acknowledgements}

The authors would like to thank all the technology-based entrepreneurs who took part in the survey. This study was conducted through financial aids from Nelson Mandela University research funds and author's own funds.

\section{Competing interests}

The authors declare that they have no financial or personal relationships that may have inappropriately influenced them in writing this article.

\section{Authors' contribution}

T.S.V.D.H. wrote the article as part of his $\mathrm{PhD}$ in Business Management and is the primary author. E.V. was the study leader, editor and mentor of this research.

\section{References}

Acemoglu, D. (2012). Introduction to economic growth. Journal of Economic Theory 147(2), 545-550. https://doi.org/10.1016/j.jet.2012.01.023

AfriSeek.com. (2013). Afri-Seek: Your first choice for African business intelligence, [Online] (1.1), viewed 1-30 April 2013, from https://www.afriseek.com/

Arregele, J., Batjargal, B., Hitt, M. A., Webb, J. W., Miller, T., \& Tsui, A. S. (2015). Family ties in entrepreneurs' social networks and new venture growth. Entrepreneurship Theory and Practice, 313-344. https://doi.org/10.1111/etap.12044

Audretsch, D. B., Belitsji, M., \& Desai, S. (2015). Entrepreneurship and economic development in cities. Annals of Regional Science, 55(1), 33-60. https://doi. org/10.1007/s00168-015-0685-x

Autio, E. (2005). Report on high-expectation entrepreneurship. Toronto: GEM Consortium.

Baker, W. E., Grinstein, A., \& Harmancioglu, N. (2015). Whose innovation performance benefits more from external networks: Entrepreneurial or conservative firms? Journal of Innovation Management, 33(1), 104-121. https://doi.org/10.1111/ jpim.12263

Baron, R. M., \& Kenny, D. A. (1986). The moderator-mediator variable distinction in social psychological research: Conceptual, strategic, and statistical considerations. Journal of Personality and Social Psychology, 51(6), 1173-1182.

Baron, R. A., \& Markman, G. D. (2003). Beyond social capital: The role of entrepreneurs' social competence in their financial success. Journal of Business Venturing, 18(1), 41-60. https://doi.org/10.1016/S0883-9026(00)00069-0

Bosma, N., Content, J., Sanders, M., \& Stam, E. (2018). Institutions, entrepreneurship and economic growth in Europe. Small Business Economics, 34(1), 1-17.

Brettel, M., Mauer, R., Engelen, A., \& Küpper, D. (2012). Corporate effectuation: Entrepreneurial action and its impact on R\&D project performance. Journal of Business Venturing, 27(2), 167-184. https://doi.org/10.1016/j.jbusvent.2011. 01.001
Brinckmann, J., Grichnik, D., \& Kapsa, D. (2010). Should entrepreneurs plan or just storm the castle? A meta-analyses on contextual factors impacting the business planningperformance relationship in small firms. Journal of Business Venturing, 25(1), 24-40. https://doi.org/10.1016/j.jbusvent.2008.10.007

Cardon, M. S., Gregoire, D. A., Stevens, C. E., \& Patel, P. C. (2013). Measuring entrepreneurial passion: Conceptual foundations. Journal of Business Venturing, 28(3), 373-396. https://doi.org/10.1016/j.jbusvent.2012.03.003

Chandler, G. N., \& Hanks, S. H. (1993). Measuring the performance of emerging businesses: A validation study. Journal of Business Venturing, 8(5), 391-408.

Chen, M., Chang, Y., \& Lee, C. (2015). Creative entrepreneurs' guanxi networks and success: Information and resource. Journal of Business Research, 68(4), 900-905. https://doi.org/10.1016/j.jbusres.2014.11.049

Chowdhury, S. (2011). The moderating effects of customer driven complexity on the structure and growth relationship in young firms. Journal of Business Venturing, 26(3), 306-320. https://doi.org/10.1016/j.jbusvent.2009.10.001

Cliff, N. (1988). The eigenvalues-greater-than-one rule and the reliability of components. Psychological Bulletin, 103(2), 276-279. https://doi.org/10.1037/ 0033-2909.103.2.276

De Carolis, D. M., Litzky, B. E., \& Eddleston, K. A. (2009). Why networks enhance the progress of new venture creation: The influence of social capital and cognition. Entrepreneurship theory and Practice, 33(2), 527-545.

De Massis, A., Audretsch, D., Uhlaner, L., \& Kammerlander, N. (2018). Innovation with limited resources: Management lessons from German Mittelstand. Journal of Product Innovation Management, 35(1), 125-146. https://doi.org/10.1111/ jpim.12373

Demil, B., Lecocq, X., Ricart, J. E., \& Zott, C. (2015). Business Models within the domain of strategic entrepreneurship. Strategic Entrepreneurship Journal, 9(1), 1-28. https://doi.org/10.1002/sej.1194

Dew, N., Read, S., Sarasvathy, S. D., \& Wiltbank, R. (2008). Outline of a behavioral theory of the entrepreneurial firm. Journal of Economic Behavior \& Organization, 66, 37-59. https://doi.org/10.1016/j.jebo.2006.10.008

Dew, N., Read, S., Sarasvathy, S. D., \& Wiltbank, R. (2009). Effectual versus predictive logics in entrepreneurial decision-making: Differences between experts and logics in entrepreneurial decision-making: Differences between experts and
novices. Journal of Business Venturing, 24, 287-309. https://doi.org/10.1016/j. novices. Journal of Busin

Durand, R., \& Vaara, E. (2009). Causation, counterfactuals, and competitive advantage Strategic Management Journal, 30(12), 1245-1264. https://doi.org/10.1002/ Strategic
smj.793

Engelen, A., Gupta, V., Strenger, L., \& Brettel, M. (2015). Entrepreneurial orientation, firm performance, and the moderating role of transformational leadership behaviors. Journal of Management, 41(4), 1069-1097.

Farrington, S. M. (2009). Sibling partnerships in South-African small and medium-sized family businesses. Unpublished doctoral thesis. Port Elizabeth: Nelson Mandela Metropolitan University.

Felzensztein, C., Ciravegna, L., Robson, P., \& Amoros, J. S. (2015). Networks, entrepreneurial orientation and internationalization scope: Evidence form Chilean small and medium enterprises. Journal of Small Business Management, 53(1), 145-160.

Hair, J. F., Black, W. C., Babin, J. B., Anderson, R. E., \& Tatham, R. L. (2006). Multivariate data analysis (6th edn.). Upper Saddle River, NJ: Pearson/Prentice-Hall.

Hair, J. F., Ringle, C. M., \& Sarstedt, M. (2011). PLS-SEM: Indeed a silver bullet. Journa of Marketing Theory and Practice, 19(2), 139-152. https://doi.org/10.2753/ of Marketing Theory

Hayter, C. S. (2016). Constraining entrepreneurial development: A knowledge-based view of social networks among academic entrepreneurs. Research Policy, 45(2), 475-490.

Hlady-Rispal, M., \& Servantie, V. (2018). Deconstructing the way in which value is created in the context of social entrepreneurships. International Journal of Management Reviews, 20(1), 62-80. https://doi.org/10.1111/ijmr.12113

Hmieleski, K. M., Carr, J. C., \& Baron, R. A. (2015). Integrating discovery and creation perspectives of entrepreneurial action: Relative roles of founding CEO human capital, social capital and psychological capital in context of risk versus uncertainty. Strategic Entrepreneurship Journal, 9(4), 289-312. https://doi.org/10.1002/ sej.1208

Huggins, R., \& Thompson, P. (2015). Entrepreneurship, innovation and regional growth: A network theory. Small Business Economics, 45(1), 103-128. https://doi. org/10.1007/s11187-015-9643-3

Jones, O., \& Jayawarna, D. (2010). Resourcing new business: Social networks, bootstrapping and firm performance. Venture Capital, 12(2), 127-152.

Kalinic, I., Sarasvathy, S. D., \& Forza, C. (2014). 'Expect the unexpected': Implications of effectual logic on the internationalization process. International Business Review, 23(3), 635-647. https://doi.org/10.1016/j.ibusrev.2013.11.004

Kariv, D. (2012). "Off stage-on stage': Men and women entrepreneurs leading change and business growth. Journal of Enterprising Communities: People and Places in the Global Economy, 6(2), 169-184. https://doi.org/10.1108/ 17506201211228967

Kile, C. O., \& Phillips, M. E. (2009). Using industry classification codes to sample hightechnology firms: Analyses and recommendations. Journal of Accounting, Auditing \& Finance, 24(1), 35-58. https://doi.org/10.1177/0148558X0902400104

Kwon, S., \& Arenius, P. (2010). Nations of entrepreneurs: A social capital perspective. Journal of Business Venturing, 25(3), 315-330. https://doi.org/10.1016/j jbusvent.2008.10.008

Lepak, D. P., Smith, K. G., \& Taylor, M. S. (2007). Value creation and value capture: A multilevel perspective. The Academy of Management Review, 32(1), 180-194. https://doi.org/10.5465/amr.2007.23464011 
Leyden, D. P., Link, A. N., \& Siegel, D. S. (2014). A theoretical analysis of the role of social networks in entrepreneurship. Research Policy, 43(7), 1157-1163. https:// doi.org/10.1016/j.respol.2014.04.010

Maine, E., Soh, P., \& Dos Santos, N. (2015). The role of entrepreneurial decisionmaking in opportunity creation and recognition. Technovation, 39-40(1), 53-72. https://doi.org/10.1016/j.technovation.2014.02.007

Makridakis, S., Hogarth, R., \& Gaba, A. (2009). Forecasting and uncertainty in the economic and business world. International Journal of Forecasting, 25(4) 794-812. https://doi.org/10.1016/j.ijforecast.2009.05.012

Memili, E., Fang, H., Chrisman, J. J., \& De Massis, A. (2015). The impact of small- and medium-sized family firms on economic growth. Small Business Economics, 45(4), 771-785. https://doi.org/10.1007/s11187-015-9670-0

Mian, S., Lamine, W., \& Fayolle, A. (2016). Technology business incubation: An overview of state of knowledge. Technovation, 50-51(1), 1-12. https://doi. org/10.1016/j.technovation.2016.02.005

Moutinho, R., Au-Yong-Oliveira, M., Coelho, A., \& Manso, J. S. (2016). Determinants of knowledge-based entrepreneurship: An exploratory approach. International Entrepreneurship and Management Journal, 12(1), 171-1971. https://doi. org/10.1007/s11365-014-0339-y

Nummela, N., Saarenketo, S., Jokela, P., \& Loane, S. (2014). Strategic decisionmaking of a born global: A comparative study from three small open economies. Management International Review, 54(4), 527-550. https://doi.org/10.1007/s11575-014-0211-x

Obloj, T., Obloj, K., \& Pratt, M. G. (2010). Dominant logic and entrepreneurial firms performance in a transition economy. Entrepreneurship Theory and Practice, 34(1) 151-170.

Peng, D. X., Schroeder, R. G., \& Shah, R. (2008). Linking routines to operations capabilities: A new perspective. Journal of Operations Management, 26(6), 730-748.

Perry, J. T., Chandler, G. N., \& Markova, G. (2012). Entrepreneurial effectuation: $\mathrm{A}$ review and suggestions for future research. Entrepreneurship Theory and Practice, 36(4), 837-861. https://doi.org/10.1111/j.1540-6520.2010.00435.x

Presutti, M., Boari, C., \& Fratocchi, L. (2007). Knowledge acquisition and the foreign development of high-tech start-ups: A social capital approach. International Business Review, 16(1), 23-46.

Rasmussen, E., Mosey, S., \& Wright, M. (2015). The transformation of network ties to develop entrepreneurial competencies for university spin-offs. Entrepreneurship and Regional Development, 27(7/8), 430-4574. https://doi.org/10.1080/0898562 6.2015 .1070536
Ritter, T., \& Walter, A. (2012). More is not always better: The impact of relationship functions on customer-perceived relationship value. Industrial Marketing Management, 41(1), 136-1441. https://doi.org/10.1016/j.indmarman.2011. Managem
11.020

Sarasvathy, S. D. (2001). Causation and effectuation: Toward a theoretical shift from economic inevitability to entrepreneurial contingency. Academy of Management Review, 26(2), 243-263. https://doi.org/10.5465/amr.2001.4378020

Sarasvathy, S. D. (2008). Effectuation. Elements of entrepreneurial expertise. Massachusetts: Edward Elgar Publishing Inc.

Shepherd, D. A., Williams, T. A., \& Patzelt, H. (2015). Thinking about entrepreneurial decision-making: Review and research agenda. Journal of Management, 41(1), 11-46. https://doi.org/10.1177/0149206314541153

Sjöholm, F., \& Lundin, N. (2010). The role of small firms in the technology development of China. World Economy, 33(9), 1117-113911. https://doi. org/10.1111/j.1467-9701.2010.01282.x

Stam, W., Arzlanian, S., \& Elfring, T. (2014). Social capital of entrepreneurs and small firm performance: A meta-analysis of contextual and methodological moderators. Journal of Business Venturing, 29(1), 152-1731. https://doi.org/10.1016/j. jbusvent.2013.01.002

Tantalo, C., \& Priem, R. L. (2014). Value creation through stakeholder synergy. Strategic Management Journal, 37(2), 1-17.

Venter, E., Farrington, S. M., \& Boshoff, C. (2012). Relational-based factors influencing successful copreneurships. Management Dynamics, 21(4), 14-30.

Walter, A., Auer, M., \& Ritter, T. (2006). The impact of network capabilities and entrepreneurial orientation on university spin-off performance. Journal of Business Venturing, 21(4), 541-5675. https://doi.org/10.1016/j.jbusvent.2005.02.005

Werhahn, D., \& Brettel, M. (2012). Validating effectual behavior as corporate orientation. In Babson College Entrepreneurship Research Conference 2010. TX Babson College.

Yang, M., \& Gabrielsson, P. (2017). Entrepreneurial marketing of international hightech business-to-business new ventures: A decision-making process perspective. Industrial Marketing Management, 64(1), 147-160. https://doi.org/10.1016/j. indmarman.2017.01.007

Zikmund, W. G. (2003). Business research methods (7th edn.). Mason: South Western Thomson. 


\section{Appendix 1}

TABLE 1-A1: Scales and items questionnaire

\begin{tabular}{|c|c|c|}
\hline Construct & Dimension & Item \\
\hline $\begin{array}{l}\text { Structured } \\
\text { networks }\end{array}$ & & $\begin{array}{l}\text { In our business when faced with a new project, we identify possible network partners in advance } \\
\text { In our business we analyse what we would like to achieve with each network partner } \\
\text { In our business we have regular discussions with our network partners about how we can support each other to achieve success } \\
\text { In our business we often analyse what business goals we would like to achieve and choose a network partner accordingly } \\
\text { In our business we have network partners who share our business goals }\end{array}$ \\
\hline $\begin{array}{l}\text { Unstructured } \\
\text { networks }\end{array}$ & & $\begin{array}{l}\text { Our employees have regular social contact with colleagues who are not part of the business } \\
\text { Our employees have regular social contact with each other } \\
\text { Our employees have regular social contact with customers } \\
\text { Our employees have regular social contact with suppliers } \\
\text { Our employees have regular social contact with entrepreneurs who have their own businesses }\end{array}$ \\
\hline $\begin{array}{l}\text { Decision-making } \\
\text { orientation }\end{array}$ & $\begin{array}{l}\text { Causal decision- } \\
\text { making orientation }\end{array}$ & $\begin{array}{l}\text { In our business we organise and implement control processes to make sure we meet our business's goals } \\
\text { In our business we have a clear and consistant vision of the business goals we want to achieve } \\
\text { In our business resources are determined on the basis of given project targets } \\
\text { In our business when deciding on possible projects, we analyse long term opportunities and select the ones we think will provide the } \\
\text { best returns } \\
\text { In our business when making decisions about business expenditure, we base them on potential returns } \\
\text { In our business we carefully design and plan business strategies } \\
\text { In our business we do competitive analyses } \\
\text { In our business we focus on market analyses and forecasts to identify risks } \\
\text { In our business we make an effort to predict the future as accurately as possible in order to prevent unpleasant surprises } \\
\text { In our business we bring in personal knowledge and experience as much as possible } \\
\text { In our business we pursue those initiatives for which we have the relevant competancies } \\
\text { In our business we invest only as much as we can afford to lose } \\
\text { In our business we invest only if the loss of the investment cannot ruin the business } \\
\text { In our business we perceive surprises as new opportunities } \\
\text { In our business we use new information as resources } \\
\text { In our business we view setbacks as new opportunities } \\
\text { In our business we approach potential partners as early as possible to co-create the future } \\
\text { In our business we enter into business relationships in which partners are willing to make commitments based on future opportunities i } \\
\text { the market place } \\
\text { In our business we view new entrants in the market as potential partners } \\
\text { In our business we attempt to shape the business environment in which we operate } \\
\text { In our business we attempt to proactively design our business environment with others } \\
\text { In our business we attempt to influence business trends }\end{array}$ \\
\hline $\begin{array}{l}\text { Perceived value } \\
\text { creation }\end{array}$ & Non-financial value & $\begin{array}{l}\text { Our business has experienced growth in sales over the past } 2 \text { years } \\
\text { Our business has experienced growth in employee numbers over the past } 2 \text { years } \\
\text { Our business has growth in profits over the past } 2 \text { years } \\
\text { Our business has improved its cashflow over the past } 2 \text { years } \\
\text { Our business has been able to invest in valuable assets } \\
\text { Our business has created financial value } \\
\text { Our business's employees are satisfied with their jobs } \\
\text { Our business's employees enjoy working for the business } \\
\text { Our business's employees find their work rewarding } \\
\text { Our business's employees find their work fulfilling } \\
\text { Our business's employees work well together } \\
\text { Our business's employees enjoy operating independently } \\
\text { Our business's employees enjoy being free from the organisational restraints of large businesses } \\
\text { Our business's employees contribute towards improving our products/services } \\
\text { Our business's employees are encouraged to experiment with innovative ideas for new processes and procedures } \\
\text { Our business's employees search for opportunities to learn and improve } \\
\text { Our business's employees learn through working in the business } \\
\text { Our business's employees learn through working with people outside the business } \\
\text { Our business's employees stay on the leading edge of new technology in order to provide excellent customer service } \\
\text { Our business's employees can anticipate customer needs } \\
\text { Our business's employees have developed specialised resources that are difficult for our competitors to copy } \\
\text { Our business's employees deliver products/services that are of high value to the end user }\end{array}$ \\
\hline
\end{tabular}

